\title{
BMS cancer spin-off raises first finance
}

Nearly a year after Bristol-Myers Squibb (BMS; Princeton, NJ) announced its intention to close the Seattle biotechnology site, two former BMS molecular immunologists have secured rights to the cancer-targeting program on which they had worked for a decade, creating Seattle Genetics (Bothell, WA) to commercialize several anticancer drugs. The new company may signify a trend by big pharmaceutical companies to spin off their promising, but secondary, technologies.

Seattle Genetics began operations quietly in December 1997 with private investment capital, and in April this year raised \$7 million in first-round financing with three venture investor groups-Olympic Venture Partners (Kirkland, WA), Sofinnova Venture Partners (San Francisco, CA), and Indosuez Ventures (Menlo Park, CA). Perry Fell, who is president and CEO of Seattle Genetics, expects the company to grow to about 24 employees in the next 18 months; a second round of financing is planned within the next 18-24 months to raise an additional $\$ 10-15$ million.

When BMS announced in April 1997 that it planned to consolidate its US operations to the East coast, the group's tumor-targeting program, which had begun in the 1980s and was consequently fairly late-stage, did not fit into BMS's larger strategy for cancer, says Sylvia Sharockman, manager of BMS public affairs. Peter Ringrose, following his appointment as president of BMS Pharmaceutical Research Institute in January 1997, decided not to pursue the program.

Soon after the announcement, Fell and Clay Siegall-who between them have 18 years of experience in molecular immunology-began negotiating with BMS to license the antibody-based cancer technology to form their own company. An agreement was finally reached in April 1998, giving their new company, Seattle Genetics, exclusive rights to the four platforms developed by the group in exchange for a onetime licensing fee and royalties on products developed. Fell previously served as director of BMS's molecular immunology department from 1989 to 1997. Siegall, who is executive vice president and chief scientific officer of Seattle Genetics, came to BMS in Seattle after three years at the National Cancer Institute (Bethesda, MD) and seven at BMS's Pharmaceutical Research Institute, first in Wallingford, CT, and then in Seattle.

A similar spin-off occurred last summer, when AdProTech (Royston, UK) was created by scientists at SmithKline Beecham (SKB; London) to commercialize protein-targeting and a number of other technologies that, while promising, were not at the top of SKB's priority list. Janet Dewdney, former director and vice president of biotechnology at SKB, said at the time, "Some projects find themselves at the bottom of the list not because they represent poor science but because they are no longer considered to be on the critical path for drug development."

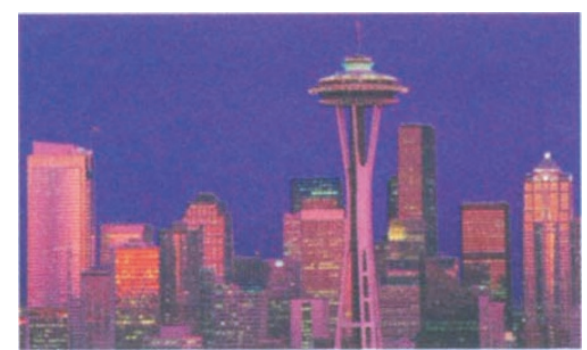

Seattle (above), the site of biotechnology growth in the Pacific Northwest.

Like AdProTech and SKB, both Seattle Genetics and BMS see their spin-off as a winwin situation. "We get a free hand to bring to full development compounds on which we have worked, and to further develop our technology platforms, and Bristol-Myers Squibb gets royalties on those drugs that they began developing," says Fell. "New partnerships with other companies will also now be possible," he adds. Time will tell whether other pharmaceutical giants-or their scientists-will spin off promising but less advanced technologies.

Perry and Siegall's portfolio for tumor targeting comprises four mature technology platforms: immunotoxins, antibody-drug conjugates, "naked" monoclonal antibodies, and antibody-delivered enzyme prodrug therapy. The first of four products currently in development will enter the clinic this year and will eventually target breast, colon, lung, ovarian, and prostate cancers. It comprises a single-chain antibody, BR96, genetically linked to a binding-defective form of
Pseudomonas exotoxin, PE40, says Fell. "BR96 sFv-PE40, a single-chain fusion toxin, rapidly internalizes; once inside the cell, the molecule stops protein synthesis through the enzymatic action of the toxin component," Siegall elaborates.

The drug's predecessor, developed by BMS, was the BR96 antibody linked to doxorubicin. Although this molecule targeted tumor tissue in humans, the drug conjugate did not show efficacy in phase II trials in March 1997, and also caused gastrointestinal toxicity. While the failure of BR96-doxorubicin probably contributed to BMS's decision to close the Seattle facility, both Fell and Siegall are optimistic about new drug conjugates, based on excellent preclinical results. "We are now evaluating more potent drugs based on the BR96-doxorubicin clinical experience, but with more stable linkers," says Fell, who also believes that the toxicity of BR96doxorubicin was due to the Fc region of the antibody. Early trials with the antibody-doxorubicin conjugate-their second productwill focus on breast and lung cancer.

Fell and Siegall expect a third drug-targeted to hematologic malignancies, including multiple myeloma, Hodgkin's disease, non-Hodgkin's lymphoma, and B-cell leukemias--to enter the clinic within 18-24 months. They are now evaluating several lead agents-including immunotoxin and a "naked" antibody targeted to the CD40 receptor-in preclinical studies and plan to start development shortly, says Siegall.

The fourth drug under development is an antibody-targeted enzyme that activates a prodrug that kills cancer cells. In preclinical work, this two-step approach resulted in complete regressions of established human tumor xenografts, "and could be applied to currently used drugs to increase their effectiveness and lower their overall toxicity," says Fell.

Vicki Brower

\section{From Genetic Systems to Seattle Genetics}

The pedigree of Seattle Genetics and its predecessor, BMS's Seattle biotechnology arm, reaches far back in the history of modern biotechnology. In the early 1980s, Bristol-Myers (pre-Squibb) began investing heavily in molecular biology and immunology. In 1985, Bristol-Myers also became one of three partners-with Syntex and Genetic Systems (Seattle, WA) - in the joint venture, Oncogen (Seattle, WA). Bristol-Myers became sole owner of the company the following year when it acquired Genetic Systems for $\$ 300$ million. Genetic Systems, founded in 1980, had been one of the pioneer biotechnology companies. Through the acquisition, Bristol-Myers gained access to the brainpower of Genetic Systems's founder, Robert Nowinski, a molecular biologist turned biotechnology entrepreneur. Nowinski, who is currently chairman of Genentech's vaccine spin-off, Genenvax, is perhaps the seminal figure in the growth of biotechnology in the Pacific Northwest, having also founded ICOS (Bothell, WA), Oncogen, and PathoGenesis (Seattle, WA). Some of the technology that grew up on BMS's Seattle biotechnology site has now become Seattle Genetics. 